HOW

Volume 28, Number 3, pages 105 - 118

https://doi.org/10.19183/how.28.3.676

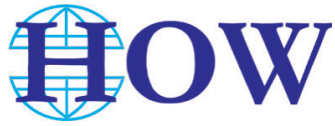

\title{
Culture and Interculture: What are We Talking about? Challenges for the ELT Community
}

\author{
Cultura e Intercultura: ¿De Qué Estamos Hablando? \\ Retos para la Comunidad de ELT
}

\section{Carlos Rico-Troncoso ${ }^{1}$}

\begin{abstract}
Talking about culture in the field of teaching foreign languages is not a new topic, but talking about interculture and interculturality is a subject that is now gaining a lot of interest in the field of ELT. Especially in the last two decades we have witnessed the growth of publications in this regard. We find all kinds of publications, but we are still having seeing the same fundamental questions that become relevant in these times of change: what we teach, who we teach it to, why we teach it, and how we teach it. These questions have always been relevant for language teachers, but today they have become even more meaningful since we are living in different times, times marked by unexpected political changes, strong economic pressures, and an unreasonable need to homogenize and standardize all the processes of teaching and learning. We must think collectively from new (postmodern) paradigms, empower ourselves, and begin to change our pedagogical practices. The aim of this paper is to share reflections on what foreign language teaching should be and how we should be thinking about culture and interculturality in our classrooms. This is an invitation to think about the need to interculturalize the teaching of the foreign language.
\end{abstract}

Keywords: culture, interculturality, intercultural approach, language teaching, language learning

He is the Academic Programs Director at the Academic Vice-Presidency in Pontificia Universidad Javeriana, Colombia. He has a Ph.D. in Intercultural Communication from Leeds Beckett University - UK, an M.A. in Social and Human Development from the CINDE and a post- doctoral degree from Universidad de Manizales, CINDE y CLACSO. He is full time teacher and researcher at the Languages Department in Universidad Javeriana. He has been a member of the board of directors of ASOCOPI (the Colombian Association of Teachers of English).

crico@javeriana.edu.co

ORCID: https://orcid.org/0000-0002-4399-3394

Received: May 31st, 2021. Accepted: July 14th, 2021.

This article is licensed under a Creative Commons Attribution-Non-Commercial-No-Derivatives 4.0 International License. License Deed can be consulted at https://creativecommons.org/licenses/by-nc-nd/4.0. 


\section{Resumen}

Hablar de cultura en el campo de la enseñanza de una lengua extranjera no es un tema nuevo, pero hablar de la intercultura y la interculturalidad es un tema que está cobrando mucho interés en el campo del ELT. Especialmente en las dos últimas décadas hemos sido testigos del crecimiento en publicaciones en este sentido. Encontramos todo tipo de publicaciones, pero aún no nos hacemos las preguntas fundamentales que cobran mucha relevancia en estos tiempos de cambio: qué enseñamos, a quién lo enseñamos, para qué lo enseñamos y cómo lo enseñamos. Estas preguntas han sido relevantes para el profesor de lenguas, pero hoy cobran sentido ya que nos encontramos viviendo tiempos diferentes, tiempos marcados por cambios políticos inesperados, fuertes presiones económicas y una necesidad desmesurada por homogenizar y estandarizar todos los procesos de enseñanza y aprendizaje de las lenguas extranjeras. Debemos como colectivo pensarnos desde nuevos paradigmas (postmodernos), empoderarnos y empezar a cambiar nuestras prácticas pedagógicas. El objetivo de este documento es compartir reflexiones en torno a lo que debería ser una enseñanza de las lenguas extranjeras en estos momentos, a cómo deberíamos estar pensando la cultura y la interculturalidad en nuestros salones de clase. La invitación es a pensar en la necesidad de interculturalizar la enseñanza de la lengua extranjera.

Palabras clave: cultura, interculturalidad, enfoque intercultural, enseñanza de lengua, aprendizaje de lengua

\section{Introduction}

I am so happy to have received the invitation to participate in HOW's 25-years Special Issue. For me it is a privilege to be able to share with all the members of our beloved ASOCOPI (The Colombian English Language Teachers Association) and with the entire academic community ideas and thoughts related to the new trends of English Language Teaching (ELT henceforth) as well as the critical and relevant aspects of Language Teaching and Teacher Education. These thoughts are deep-rooted in my experience and my research interests as a teacher educator for more than 30 years.

Mainly, I will refer to two aspects that have raised issues in our congresses and which have led to an increase in publications, mostly in the last decade. These topics concern culture and interculturality and whether they can be taught in the ELT classroom or if they can be taken as approaches to plan the teaching of foreign languages. To understand these concepts, I will first refer a little to what has happened in my life as a language teacher, 106 how I understood culture and how I approached it. Then I will review two epistemological paradigms to better understand how the concept of culture has changed throughout history around the world and to mention the importance of positioning the intercultural approach as a way of teaching foreign languages and culture.

Let us first consider how my view about culture has evolved as my professional growth has taken place. Back in the late 80 s when I started to study languages as my chosen major in Universidad del Tolima, it was an exciting experience because I was training to be a language 
teacher, particularly an English teacher. What a great challenge. Being honest, I did not have a good command of this language. I was a student who came from rural and public schools. When I started my university studies, my knowledge of English as a foreign language was very rustic and did not exceed a small repertoire of English language words. At first, every language class was a nightmare. I had to learn lists of words and learn some dialogues to be acted out in front of the class. The good thing was, I was passionate about linguistics and literature. This helped me a lot in the sense of being curious about languages (being a language analyst) and sensitive to understanding aesthetically the different ways of being in the world (the realm of literature).

As I advanced in my academic career, I attended English courses in literature and culture. Unfortunately, those courses only referred to concrete encyclopedic and factual knowledge about culture, either North American or British. That was the first problem I faced, to link the concept of culture to a nation or country. This narrow and misplaced view of culture brought about serious consequences of stereotyping and minimizing any culture. It completely disregarded the cultural capital of the collective groups, and what it comprises and means, to a simple idea of referring to culture as a product or an end.

As I said, my interests in linguistics and language teaching shaped my views about culture. As a student of languages at that time, we talked about the importance of teaching culture because we believed that language was part of culture and culture was represented by that language. In that sense, it was important to study how any community or particular social group used a language. In the research studies we carried out, we started to differentiate the respective groups of language users and what they produced in terms of language patterns and their cultural heritage (literature, music, food, and some others). As a result, the years passed but the conceptualization of culture still remained the same provoking the consolidation and reinforcement of inappropriate social representations of culture. A remark that emerges then is how we, students, teachers, and language users, construct our own social representations of culture e.g., whether we are culture consumers or culture producers. Culture is something external to the individual or we are embedded in it.

To sum up, language and culture were unfortunately seen as 'ends' which were related to a specific community placed in a physical setting and with its specific material achievements -artefacts- which represented the community's social patrimony and symbolic capital that served to perpetuate relationships of power and domination. They distinguished insiders from outsiders and transmitted information only about the people of the target country. In this respect, language teaching, according to Kramsch (1993), "has usually ignored the fact that a large part of what we call culture is a social construct, the product of self and other perceptions" (p. 205). 
In fact, as years passed, I was inclined to study linguistics (theoretical and descriptive); my view about culture was influenced by this discipline that let me talk about communities of speech and the importance of them within a culture. I realized that language was part of the symbolic world of culture. Thanks to language we can represent and apprehend the world. Language allows us to be in the world (being seeing and heard). Language is the vehicle that mobilizes cultural and social groups; it is the social glue that joins the individual to the community and the tool that allows us to maintain the intersubjective relationships and allows us to live together. As such, culture was understood as the ways of people, the ways of being in the world and that is why we can talk about cultures (in the plural). Having those ideas in mind, I understood that I had broadened that concept of language and culture. But at the end, it was the same thing; those concepts were restricted to a specific discipline. Culture is polysemic and implies different perspectives to be understood. Maybe that was the idea that encouraged me to study social sciences more deeply.

Nowadays, I am much concerned about the importance of the social sciences in ELT. I have seen that my view about culture was absolutely limited in every sense. What I mean is that the narrow conceptualization of culture was governed by the way I approached it. I tried to look for a right definition of culture based on a specific discipline (linguistics, sociology, anthropology, etc.) but culture was more than that. Then, what is the critical standpoint? The answer is simple; the problem is not how to conceptualize the object, but how to approach it. The approach has to do with the epistemological perspective that we take, with the positionings that we adopt. This influences the way of conceptualizing the object (Rico-Troncoso, 2012).

Basically, I am going to refer to the latest two big approaches that language teachers have gone through over the last two centuries: modernism and postmodernism. These two approaches have influenced everything and particularly the way culture has been defined. Let me summarize the main characteristics of these two approaches:

Modernism: (XVII y XVIII) the basis is rationale. Centrality turned around the importance of science (Harvey, 1989a).

- The enlightenment project of modernity based on a positivist approach to knowledge. It was believed that there was only one answer to any question. And it was followed by the belief in absolute truths, and rational planning under standardized conditions of knowledge and production as well as the emergence of nation-states.

- Culture was initially seen as part of civilization from an ethnographic sense which includes knowledge, beliefs, arts, morals, laws, customs, and other capabilities acquired as part of being a member of a society.

- Cultural anthropologists defined culture as a "collection of traits, to one which emphasizes pattern and configuration" (Hall \& Reed, 1990). 
- Culture was viewed as an embedded-in patterns system. It is "the way of life of a people" which entails learnt behavior patterns, attitudes, and material things (Geertz, 1975).

From my perspective, the problem with modernism is that we, as language teachers, tend to package everything. We are looking to label things and people. We attempt to classify people, behaviors, and patterns. Under these circumstances, culture can be perfectly taught as content or as another aspect of language. From the modern perspective, culture is a notion which some specialists can have access to, and study it fragmentally.

Postmodernism: (XIX century - present) the basis is a general suspicion of reason and a strong position for sensitivity (Harvey, 1989b). The postmodern thought has been strongly influenced by prominent thinkers like Michel Foucault, Jean Francois Lyotard, and Jacques Derrida, among others.

- The postmodern shift would be characterized by a profound revolution in the structure of feeling.

- The central cornerstone is plurality instead of unity.

- Postmodernism made a shift in distinguishing the set of assumptions, experiences, and propositions to promote sensibility, practices, and discourse formations.

- In the frame of this contemporary trend, culture is seen as involving a number of interrelated complex systems that may include an individual's mental representations of language and culture as a complex social system.

- The discussion turns around the perspectives on culture as a product, as discourse, as practice, and as ideology (Baker, 2015).

- Culture is viewed as collectively constructed through intersubjective relationships.

This approach views culture as a combination of complex systems based on the mental depictions individuals have about language as well as their perception of it as an intricate system constructed within and through discourse. Culture is viewed as collectively constructed through the intersubjective interactions. It is an evolving dynamic system of interactions and should be defined from a multidisciplinary perspective (Spencer-Oatey \& Franklin, 2009).

With postmodernism language teachers and teacher educators have advanced with the conceptualization of culture. Nevertheless, from my perspective, the language teaching context is still defined by the modernist view. In the field of language teaching, teachers are still concerned about the analogy of the iceberg when defining culture. We infer from the iceberg analogy that there are two views through which culture has been understood. Bennett (1998) distinguishes them as 'the upper-case Culture' and 'the Lower-case culture'. The former is related to kinds of things included in area studies or history courses: literature, drama, fine 
arts, classical music, etc. The study of these areas constitutes much of the curriculum in both international and multicultural education. The latter refers to the psychological features that define a group of people -their everyday thinking and behavior-rather than to the 'institutions' that they have created. With this perspective, culture is the "learned and shared patterns of beliefs, behaviors, and values of groups of interacting people "(Bennett, 1998, p. 3). The distinction has been called more in academic terms as 'objective culture' and 'subjective culture' respectively. The debate is not whether these definitions are right or wrong; rather, the point is to divide culture in such a way. Culture should not be viewed as separated or compartmentalized. Unquestionably, this analogy does not contribute to understanding what culture is or means.

Of interest here is that lots of attempts have been made to define the concept of culture, and perhaps to elaborate an appropriate definition is not easy. What one can say from all definitions given about culture is that most of them come to the same conclusion; culture is the symbolic representation of the everyday life of a group. In everyday life, we refer to rituals of interaction, the styles of living, and the objects used by a group (or artefacts). Furthermore, culture enables the interpretation of social life; thus, it provides orientation for actions and behavior. In this regard, culture is seen as a dynamic process of change.

As a symbolic system, the interpretations of culture could be ambiguous and could result in confusion or conflict when encountering representatives from different groups or cultures. For that reason, Patterson (as cited in Fennes \& Hapgood, 1997) states that "culture is an identifiable complex of meanings, symbols, values and norms that are shared consciously or unconsciously by a group of people" (p. 15). According to these ideas, a more refined approach about culture is taken by the Centre for Contemporary Cultural Studies $(\mathrm{CCCS})^{2}(1997)$ at the University of Birmingham (UK) which states that:

Culture of a group or class includes the special and distinct lifestyle of this group or class. The meanings, the values and ideas as they are reflected in the institutions, in the social relationships, in systems of beliefs, in customs and traditions, in the use of objects, and in material life. Culture is the specific shape in which this material and this social organisation is expressed. Culture includes 'maps of meanings' which make these things understandable for its members. These 'maps of meanings' are not carried in one's brain. They are represented in the forms of the social organisation and relationships through which the individual becomes a 'social individual'. Culture is the way through which the relationships of a group are structured and shaped; but it is also the way they are experienced, understood and interpreted. (p. 15)

The Centre for Contemporary Cultural Studies was led by Stuart Hall. A Jamaican-British academic, writer, and cultural-studies pioneer, who was born in Kingston, Jamaica, in 1932, and died in London in 2014. Hall joined the CCCS at Birmingham University in 1964. He took over from Hoggart as director of the Centre in 1968, and remained there until 1979. 


\section{Culture and Language Teaching: Bridging the Gaps}

So far, I have dealt with the concept of culture but I have made little mention of how it is seen in the field of language teaching. When language teachers are asked about what culture means to them, some of them answer merely by listing subjects such as literature, arts, history and geography. These subjects are placed under the umbrella term 'civilization' or 'big C' culture as opposed to the category of 'little c' culture (Lázár et al., 2007). There are some others that can refer to the embedded-pattern system behaviors of a group. The definitions of culture, according to Lázár (2007), suggest that the cultural elements to be included in language teaching cover much more than the traditional list of compulsory facts about the civilization of one or two of the target cultures. It also includes "information about beliefs, customs, social practices, values and behavior" (Lázár et al., 2007, p. 8). Again, this is a very reductionist view of culture.

In a similar vein, Holliday states that within Applied Linguistics (AL) and Intercultural Communication (IC), many researchers regard culture as "a preference for certain patterns of communicative behaviour" (Holliday et al., 2010, p. 61). This is related more to the functionalist view of language teaching where culture is seen as,

Background and resource, and where the human subject is only seen in his/her role of executor of functions. In other words, culture is viewed as behaviour (i.e. 'X' people don't smile in public), or as fixed values and beliefs, separated from social interaction and socio-political realities (i.e. ' $\mathrm{X}$ ' culture values the elderly). (Holliday et al., 2010, pp. 61-62)

Such reductionism has been characteristic of AL and IC where ethnicities and cultural identities have been reduced to lists of linguistic and interactional elements that can be used in the communicative situations.

In language teaching, culture is a process that both includes and excludes; as Kramsch (1998) asserts: "culture always entails the exercise of power and control" (p. 8). I can see in language teaching how this relationship of power is exercised when we see the hegemonic effects of the dominant culture --the target culture-- towards the minority culture (the in-group culture that functions as the majority). It is clear that in language teaching, the dominant perspective has been the 'adaptive system' which has to do with the idea of "relating communities to their ecological settings" (Paulston, 2005, p. 278). What Paulston states is that culture should not be understood under the adaptive system due to its very superficial level of understanding. She mentions that there is another paradigm which offers a more realistic definition of culture. This new paradigm includes the ideational theories in which, according to Keesing (as cited in Paulston, 2005, p. 278), culture can be interpreted from three systems, either as (a) a cognitive system as inferred ideational codes lying behind the realm of observable events, or as (b) a structural system where cultures are viewed as 
shared symbolic systems that are cumulative creations of mind. Keesing seeks to discover in the structuring of cultural domains --myth, art, kinship, language-- the principles of mind that generate these cultural elaborations; and, culture as (c) a symbolic system of shared symbols of meanings. Here culture is an identifiable complex of meanings, symbols, values and norms that are shared consciously or unconsciously by a group of people.

Up to here, I have to think that culture in language teaching, by its very nature, is associated with social groups (Spencer-Oatey \& Franklin, 2009). It is true that culture is not a monolithic entity that can be packed or easily defined. Definitions of culture usually coincide in four of the main characteristics:

- Culture is manifested through regularities, some of which are more explicit than others (embedded-in pattern system).

- Culture is associated with social groups, but individuals within those groups may portray variations (culture as ways of life of a people - Hall \& Reed, 1990).

- Culture affects people's behavior and interpretations of behavior (culture as ideology). Halliday et al. (2004), based on the theory of social action, views culture as a constructed social practice in which it is the result of a negotiated process.

- Culture is acquired and/or constructed through interaction with others (culture as discourse). Kramsch (2001) talks about discourse communities and how their shared stories make the members part of a social group which not only shares a language but also the topics they chose to talk about, the way they present information, and the style with which they interact.

As a conclusion, from a postmodernist approach, I entirely believe that language teachers have to theorize and problematize the concept of culture in the field of ELT. We are culture and culture is part of us. It is not external. My suggestion is to overcome the dichotomies of the 'big C' and 'small c', and to be much more open minded in viewing culture as a discourse, as an ideology, and as a practice. In other words, culture is the way of being in the world. It is the way of exercising our condition as individuals and social human beings; hence, that is why culture is a social practice, is the result of a negotiated process, and is in a permanent construction and change.

What it is clear is that the new tendency of language teaching should be based on the four teaching needs (Kramsch, 1993): (1) The intercultural sphere need (by this, we mean that we are not alone in the world, we are surrounded by cultures), (2) the need to approach culture as an intercultural process (which means that for understanding a culture, we need to adopt an intercultural approach), (3) the culture as a differential process (it means that culture cannot be packaged and homogenized in the same way), and (4) the need of crossing disciplinary boundaries (that is, that culture needs to be understood under different perspectives). 
The conception of culture and the role of culture have impacted language teachers in the sense of being aware of what culture embraces: self-awareness, the ability to look at himself/herself as an outsider, the skill to be a cultural mediator and cultural prod, the talent to evaluate different viewpoints, the aptitude to read the cultural contexts and to avoid bias related to others' identities (Rico, 2018). Perhaps the challenge is how to bring all these aspects to the language classroom. What I propose is to work on the sources of culture and take a critical perspective to decolonize the different meanings of culture. In the following graph, I suggest a route that needs more developments in our ELT context.

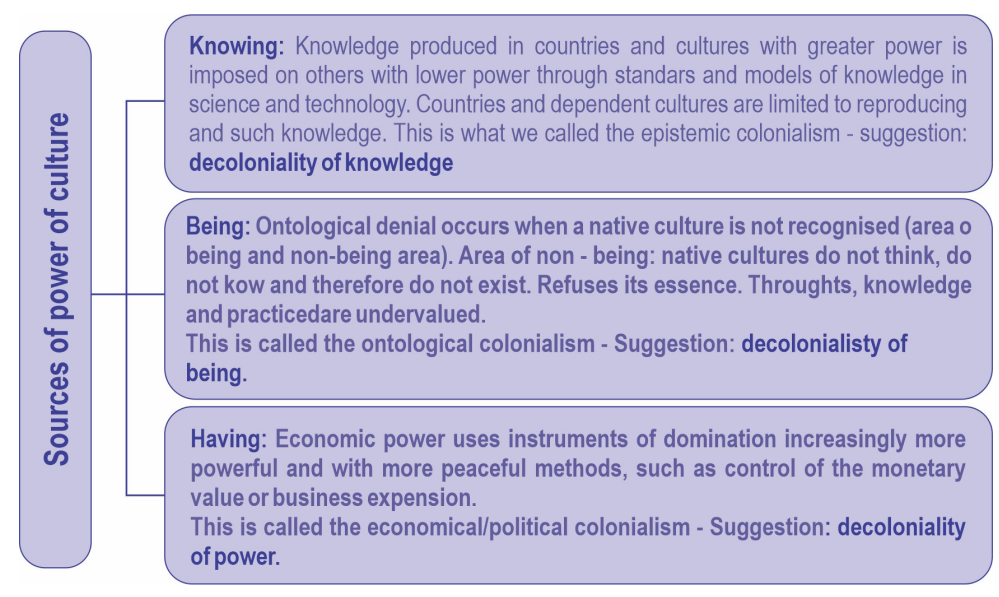

Figure 1. Sources of power of culture.

Certainly, in language teaching, culture should not be related to any language or any nation. Language users do not need to be native or non-native speakers of any language (on the contrary, this modernist idea is used to discriminate against groups and reinforce the supremacy of other cultures). From a postmodernist perspective, we avoid this colonized discourse of knowing, being, and having. We prefer to talk about language users and cultural producers. Culture is not a content that one can teach or something that one can learn. Culture is there with us; we need to comprehend it and interact with/within it. Definitely, I am convinced that in our classrooms, we need to work on developing students' competences for being good ethnographers. Students should take the role of comparative ethnographers who observe the world in a critical manner by creating their own hypotheses and sharing their experiences with others. We undeniably need to develop the intercultural approach in our language classrooms. 


\section{The Intercultural Approach in ELT: Towards a New Challenge}

I am convinced that teaching and learning a language is not just developing skills or competences that allow learners to be effective in communicative processes. Teaching and learning a language means understanding that as social human beings we interact with each other, we understand that the other person by nature is different and depicts different ways of doing, knowing, and being in the world. Perhaps if we are aware of this fact, we will have already made significant progress in the processes of social interaction. These kinds of approaches are what we need to understand in the field of ELT. It is not necessary to be a sociologist or anthropologist or even linguist to understand that what is required is a completely different approach to teaching and learning a foreign language: the intercultural approach. What I suggest is that we need to change the paradigm of seeing culture as a "product". Culture is a means by which we signify and build our identities. Languages as culture are very complex processes that are related to other aspects of the individual, the society, politics, ideology, and so on. Additionally, we need to know that when people interact in a language which is foreign to at least one of them, the shared meanings and values they convey by language cannot be taken for granted.

We cannot continue to think that the best language learner is one who is very close to mastering the grammar and vocabulary that a native speaker possesses. The objective of language teaching should no longer be defined only in terms of acquiring communicative competence in a foreign language as I mentioned before. Teachers now have a responsibility to develop intercultural communicative competence (ICC henceforth) (Rico, 2018). Facing the ICC requires special characteristics. According to Sercu et al., (2005), these characteristics and competences have been identified as a desire to be part of the foreign culture, selfawareness, and the ability to look from the outside; the ability to act as a cultural mediator; the ability to assess the views of others; the ability to consciously employ cultural learning skills and to read the cultural context; and, lastly, understanding the fact that individuals cannot be reduced to their collective identities.

Language teachers should begin to take seriously the concept of a language as a means of communication and interaction with people from other cultures. It is known that in learning another language, students are exposed to one or more social groups and their cultural practices - and inevitably learn something from these cultures (Byram \& Fleming, 1998). Therefore, any effort made in order to develop intercultural communicative competence should not be underestimated. Clearly, in the light of all these approaches, having clarity on what is challenging in the contexts of teaching a foreign language is important. Thus, the question arises about the type of approach that should be privileged in the teaching of a foreign language. Risager (1998, as cited in Rico 2018, p. 87) makes a wonderful distinction 
of different approaches: a monocultural approach, a multicultural approach, an intercultural approach, and a transcultural approach.

\section{The Monocultural Approach}

It is based on the concept of a single culture, associated with specific people, a specific language and normally with a specific territory. This approach focuses on the culture of the country or countries where the language is spoken (target countries). It has also been called "the foreign language approach". It does not focus on the learner's country or on the relationship between the target countries and that of the learner or any other. This approach has been the dominant paradigm in teaching foreign languages in Western countries since the last century. Today, it has been called into question, above all, because it is based on the concept of a dominant culture.

\section{Multicultural Approach}

This approach is based on the fact that many cultures can coexist within the boundaries of one of these and within the same society or state. For some groups in a society, the 'national' or standard/official language is their mother tongue; for others it is the second language; or for others it is a foreign language. This approach focuses on the ethnic and linguistic diversity of the target country or countries. It also focuses on the country's ethnic and linguistic diversity of the learners and their migration relations (Risager, 1998). Kramsch (1998) states that the term 'multicultural' is frequently used in two ways. In a social sense, it indicates the coexistence of people from many backgrounds and ethnicities such as in 'multicultural societies'. And in an individual sense, this term characterizes people belonging to various discourse communities and those who therefore have the linguistic resources and social strategies to join and identify with various cultures and with various ways to use the language (Kramsch, 1998).

\section{Intercultural Approach}

It is based on the concept that different cultures are structurally related to each other. Therefore, this concept encompasses the encounter of cultures, including attempts to deal with, understand and recognize the differences between them. From this approach, teaching can be characterized by attitudes of cultural relativism and a desire to assume a non-ethnocentric perspective of the cultures involved. Here the target language is taught as if it were the students' mother tongue; however, "the objective is to develop intercultural and communicative competence, a competence that allows the learner to function as a mediator between two cultures" (Risager, 1998, pp. 244-245). Kramsch (1998) states that the term 'intercultural' usually refers to the encounter of two cultures or two languages crossing 
political boundaries of nations or states. This term also refers to communication between people from different ethnic, social, and gender cultures within the boundaries of the same national/official language. Therefore, intercultural communication is associated with matters of bilingualism and biculturalism (Kramsch, 1998).

\section{The Transcultural Approach}

This approach has, as a starting point, the intertwined nature of cultures as a common condition for everyone. Cultures are being permeated into changing combinations depending on migration and tourism, global communication systems for the masses and private communication, economic interdependence, and the globalization of goods production. The extensive use of whichever of a number of languages as the lingua franca is one of the expressions of an internationalized world. The transcultural approach focuses on the lives of individuals and groups in contexts characterized by, more or less, their cultural and linguistic complexities. Here the target language is used but in such a way that learners are also aware that other languages are used.

\section{Final Remarks and Conclusions}

Definitely, we need to broaden the concept of culture via considering a multidisciplinary perspective. Culture cannot be packed in compartments or seen under just one specific field of study. My suggestion is to adopt a real postmodernist approach to language and culture (post-structuralist view). Making a change in our teaching methods is necessary. In my point of view, language teachers do not need more of the communicative approach. They do not need to continue to express meaning in a vacuum. Today, language and the teaching of foreign language is embedded and is part of the individual, the context, the society, and the culture. My suggestion is to adopt an intercultural approach in ELT.

Adopting an intercultural approach will mean that our classrooms will become ideal scenarios or laboratories to conduct cultural studies, develop intercultural competences and interpersonal skills that will allow us to accept and live with the differences in intercultural groups. In other words, as Sercu (2006) and Peña-Dix (2018) suggest, we need to interculturalize foreign language education. In particular, Sercu (2006) suggests that, "The main objective of foreign language education is no longer defined strictly in terms of the acquisition of communicative competence. Teachers are now required to teach intercultural communicative competence" (p. 55). In fact, in an investigation carried out in Spain, Sercu et al., (2004) explored the EFL secondary school teachers' perceptions of their culture-teaching practice and their role as mediators of language and culture in the foreign language class. Further research that was part of a larger comparative study in seven countries (Belgium, Bulgaria, Greece, Poland, Mexico, Spain, and Sweden) found the importance of the 
integration of language and culture in the language classroom. No teachers admitted to dealing exclusively with language and excluding culture from the foreign language class; on the contrary, teachers were aware of the role that culture plays in their foreign language class and were willing to interculturalize foreign language education.

The great challenge for teachers in Colombia and Latin America is not to fall into the trap of using interculturality only as a touch-up speech to promote inclusion or be aware of the existence of differences. It is clear that in many cases the intercultural discourses are used to hide-with rhetorical strategies - the existent political, economic, and social discriminations. In this sense, the true intentions are hidden (Zarate, 2014).

It is in the dialogue between cultures that frictions occur and unpredicted behaviors emerge. As long as we are not competent to deal with differences and diversity, we homogenize and standardize everything and everyone (this idea promotes the cultural homogenization). If human beings lose their personal and cultural identity, they also lose their being, essence, and relevance (Zarate, 2014).

Finally, it is the interaction between cultures, exchange and communication, through which the individual recognizes and accepts the reciprocity of the culture of the other. None of the cultural relationship is egalitarian. If interculturality means egalitarian relationships, it would be easy to understand the balance of power between knowledge, being, and having of both cultures; generally, this does not take place because of the sources of power of culture mentioned in Figure 1 above. We have to be very careful since interculturality as discourse has been used by dominant groups as a mechanism to assimilate the minority cultures. My invitation is to think about the nature and development of the bilingual programs or the intercultural bilingual education programs in our country.

\section{References}

Baker, W. (2015). Understanding culture through ELF. In Culture and identity through English as a lingua franca: Rethinking concepts and goals in intercultural communication. De Gruyter Mouton.

Bennett, J. M. (2004). Basic concepts of intercultural communication. Selected readings. Intercultural Press, a Nicholas Brealey Publishing Company.

Byram, M., \& Fleming, M. (1998). Language learning in intercultural perspective. Approaches through drama and ethnography. Cambridge University Press.

Centre for Contemporary Cultural Studies (CCCS) (1997). University of Birmingham. UK. https://www.birmingham.ac.uk/events/events/CCCS-conference-Birmingham-Centre-forContemporary-Cultural-Studies-50-Years-On.aspx

Fennes, H., \& Hapgood, K. (1997). Intercultural learning in the classroom. Crossing borders. Cassell Council of Europe Series. 
Geertz, C. (1975). The interpretation of cultures. Basic Books.

Kramsch, C. (1993). Context and culture in language teaching. Oxford University Press.

Kramsch, C. (1998). Language and culture. Oxford University Press.

Kramsch, C. (2001). In Intercultural communication. In D. Nunan \& R. Carter (Eds.), The Cambridge guide to teaching English to speakers of other languages (pp. 201-206). Cambridge University Press.

Lázár, I., Huber-Kriegler, M., Lussier, D., Matei, G., \& Peck, C. (2007). Developing and assessing intercultural communicative competence. Council of Europe Publishing.

Hall, E., \& Reed, M. (1990). Culture is communication. In Understanding cultural differences: Germans, French and Americans. Intercultural Press.

Harvey, D. (1989a). Modernity and modernism. In The condition of postmodernity: An enquiry into the origins of cultural change. Blackwell.

Harvey, D. (1989b). Postmodernism. In The condition of postmodernity: An enquiry into the origins of cultural change. Blackwell.

Holliday, A., Hyde, M., \& Kullman, J. (2010). Intercultural communication: An advance resource book for students. Routledge Applied Linguistics.

Paulston, B., \& Kiesling, S. F., (2005). Intercultural discourse and communication (essential readings in linguistics). Blackwell Publishing.

Peña-Dix, B. M. (2018). Developing intercultural competence in English language teachers: towards building intercultural language education in Colombia. Durham University. http://etheses.dur.ac.uk/12619/

Rico Troncoso, C. (2012). Language teaching materials as mediators for ICC development: a challenge for materials developers. Signo y Pensamiento, 31(60), 130-154.

Rico Troncoso, C. (2018). La competencia comunicativa intercultural (CCI) en los contextos de enseñanza del inglés como lengua extranjera. Signo y Pensamiento, 37(72), 77-94. https://doi. org/10.11144/Javeriana .syp37-72.ccic

Risager, K. (1998). Language teaching and the process of European integration. In M. Byram \& M. Fleming (Eds.), Language learning in intercultural perspective: Approaches through drama and ethnography (pp. 242-254). Cambridge University Press.

Sercu, L., Bandura, E., Castro, P., Davcheva, L., Laskaridou, C., Lundgren, U., et al., (2005). Foreign language teachers and intercultural competence: An international investigation. Multilingual Matters.

Sercu, L. (2006). The foreign language and intercultural competence teacher: The acquisition of a new professional identity. Intercultural Education, 17, 55-72.

Sercu, L., \& García, M., \& Castro, P. (2004). Culture teaching in foreign language education: EFL teachers in Spain as cultural mediators. Revista Internacional de Didáctica de las Lenguas Extranjeras, 1, 85-102.

Spencer-Oatey, H., \& Franklin, P. (2009). Intercultural Interaction: A Multidisciplinary approach to intercultural communication. Palgrave Macmillan.

Zárate Pérez, A. (2014). Interculturalidad y decolonialidad. Tabula Rasa, 20, 91-107. 